\title{
EFFECT OF COMPOST AND NPK WITH BIOFERTILIZERS ON GROWTH AND ESSENTIAL OIL PRODUCTION OF LEMONGRASS (CYMBOPOGON CITRATUS)
}

\author{
M.A.H. Abdou ; A.A. El-Sayed"; R.A. Taha ${ }^{*}$ and M.K. El-Nady ${ }^{* *}$ \\ *Horticulture Dept., Fac. Agric., Minia Univ., Egypt. \\ ${ }^{* *}$ Hort. Res. Inst., ARC, Egypt.
}

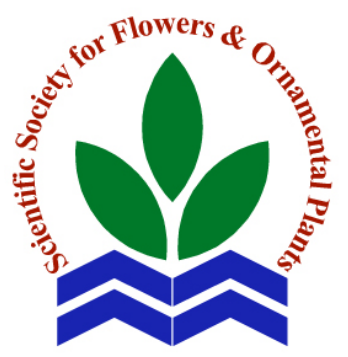

Scientific J. Flowers \& Ornamental Plants, 1(3):243-252 (2014).

Received:

$4 / 11 / 2014$

Revised by:

Prof. Dr. M.S. Hanafy, Cairo Univ.

ABSTRACT: A field experiment was carried out at the Nursery of Fac. Agric., Minia Univ. during the two successive seasons of 2011/2012 and 2012/2013 to explore the effect of three compost levels $(0,4$ and 8 ton/fed) and four mineral NPK/biofertilization treatments on vegetative growth and essential oil of lemongrass plants.

Obtained results proved that vegetative growth characters (plant height, number of tillers/plant, fresh and dry weights of leaves/fed and essential oil percent and yield per fed were considerably augmented due to the use of both low and high compost levels, with the high one ( 8 ton/fed) being much more effective. Concerning mineral/biofertilization treatments, both $100 \%$ NPK and $75 \%$ NPK + E.M. + yeast treatments out grew the other two treatments $(75 \%$ NPK + E.M. and 75\% NPK + yeast) in producing higher values of growth and essential oil parameters. The best overall results were obtained when lemongrass plants were supplied with compost at the level of 8 ton/fed and fertilized with $75 \%$ NPK combined with E.M. and yeast.

Prof. Dr. E.A.E. El-Ghadban, Key words: Lemongrass, Cymbopogon citratus, compost, NPK, Hort. Res. Inst., ARC. biofertilizer, E.M., yeast, vegetative growth, essential oil.

\section{INTRODUCTION}

Lemongrass (Cymbopogon citratus, Stapf), which belongs to Fam. Gramineae, is one of the essential oil crops. It is grown in many tropical countries in South America, as well as, Asia and Africa (Bagaturiya, 1990). It is turfied perennial grass with numerous stiff stems arising from a short, rhizomatous rootstock. The leaves are $100 \mathrm{~cm}$ long and 3 $\mathrm{cm}$ wide and used as a source of cellulose and paper production (Ciaramello, 1973). Essential oil content of the stems and leaves average $0.25-0.35 \%$ with citral being the main component $(80-86 \%)$.

Among the most important agricultural practices and organic and mineral NPK fertilization, as well as, biofertilization treatments like effective microorganisms. and yeast. The role of organic fertilization on augmenting vegetative growth and essential oil was demonstrated by different authors on various medicinal and aromatic plants like lemongrass (Maheshwari et al., 1991; Naguib, 2002 and Adholeya and Prakash, 2004), basil (Baeck and Park, 2001 and Carlen et al., 2004), rosemary (Khalil, 2002), mint (Abdou et al., 2012) and marjoram (Abdou et al., 2014). The efficiency of mineral NPK, however, was reported by Agina et al. (2001) on lemongrass, Sakr (2001) and El-Shora (2009) on mint, Singh et al. (2004), Golez et al. (2006) and Rao et al. (2007) on basil, Singh (2004) on rosemary and Rajab (2014) on marjoram. The positive influence of biofertilizers, 
represented by Effective microorganisms and yeast was clarified by Harridy et al. (2001) and Mazrou (2008) on lemongrass, Hussein et al. (2008) on marjoram, Abd El-Raaof (2009) on borage, Abdou et al. (2009) on guar and Ali (2013) on African marigold for E.M. and by Badran et al. (2002) and ElHindi and El-Boraie (2005) on marjoram, Naguib (2002) on lemongrass, Salman (2006) and Abd El-Salam (2014) on basil and Shalan (2013) on mint concerning yeast.

\section{MATERIALS AND METHODS}

This experiment was conducted in the Nursery of Fac. Agric., Minia Univ. during 2011/2012 and 2012/2013 seasons. This paper was aimed to study the effect of three compost levels and four NPK/biofertilization treatments and their interaction on vegetative growth characters and essential oil parameters of lemongrass (Cymbopogon citratus) plants.

Mother plants were divided on Nov. $11^{\text {th }}$ and Nov. $17^{\text {th }}$ for the first and second seasons, respectively. Uniform and healthy divisions were planted in $15 \mathrm{~cm}$ clay pots, then transplanted on March $15^{\text {th }}$ of both seasons to the open field. Field experimental units were $2.0 \times 1.2 \mathrm{~m}$ included 5 rows 65 $\mathrm{cm}$ apart with 3 plants in the row spaced at $40 \mathrm{~cm}$ between each plot contains 9 plants. Physical and chemical soil properties are shown in Table (a).

A split plot design in complete randomized block arrangement, with three replicates was followed in this experiment.
The main plot consisted of three compost levels, 0,4 and 8 ton/fed, while the sub plot contained four mineral NPK/biofertilization treatments, namely, 100\% NPK, 75\% NPK + E.M., 75\% NPK + yeast and 75\% NPK + E.M. + yeast. Mineral NPK was used at the rate of $400 \mathrm{~kg}$ ammonium sulphate $(20.6 \%$ $\mathrm{N}), 300 \mathrm{~kg}$ calcium superphosphate $(15.5 \%$ $\left.\mathrm{P}_{2} \mathrm{O}_{5}\right)$ and $150 \mathrm{~kg}$ potassium sulphate $(48.5 \%$ $\mathrm{K}_{2} \mathrm{O}$ ) for the treatment of $100 \%$ NPK. While $75 \%$ NPK was represented by 300, 225 and $112.5 \mathrm{~kg} / \mathrm{fed}$. These fertilizer amounts were divided into three equal batches and added 3 weeks from planting date and 21 days after the first and second cuts for each season. Concerning E.M., it was applied three times to the soil around the plants $\left(50 \mathrm{~cm}^{3} /\right.$ hill where $1 \mathrm{ml}=10^{7}$ cells of bacteria), while yeast was foliar sprayed at the concentration of $5 \mathrm{~g} / \mathrm{l}$ three times. The first application of E.M. and yeast was added after 2 weeks from planting date and repeated 2 weeks after the first and second cuts. Other agricultural practices were performed as usual.

For each cut, data were recorded for plant height $(\mathrm{cm})$, number of tillers/plant, leaves fresh and dry weights/fed, essential oil $\%$ and essential oil yield/fed. Essential oil in the fresh leaves was determined according to British Pharmacopoeia (1963). Obtained date were statistically analyzed according to MSTAT-C (1986) and differences between the means were tested using the L.S.D. at $5 \%$.

Table a. Physical and chemical properties of the soil.

\begin{tabular}{|c|c|c|c|}
\hline Soil Character & Value & Soil Character & Value \\
\hline Sand \% & 28.30 & Available P \% & 15.13 \\
\hline Silt \% & 29.95 & Exch. $\mathrm{K}^{+} \mathrm{mg} / 100 \mathrm{~g}$ & 2.32 \\
\hline Clay \% & 41.75 & Exch. $\mathrm{Ca}^{++} \mathrm{mg} / 100 \mathrm{~g}$ & 31.77 \\
\hline Soil type & Clay loam & Exch. $\mathrm{Na}^{+} \mathrm{mg} / 100 \mathrm{~g}$ & 2.46 \\
\hline Organic matter \% & 1.54 & \multirow{5}{*}{$\begin{array}{c}\text { DTPA } \\
\text { Ext. ppm }\end{array}$} & 8.50 \\
\hline $\mathrm{Ca} \mathrm{CO}_{3} \%$ & 1.58 & & 2.07 \\
\hline pH (1:2.5) & 7.86 & & 2.74 \\
\hline E.C. (m mhos/cm) & 1.08 & & 8.24 \\
\hline Total N \% & 0.07 & & \\
\hline
\end{tabular}




\section{RESULTS AND DISCUSSION}

\section{1- Vegetative growth characters:}

The four studied vegetative growth characters, plant height, number of tillers/plant and leaves fresh and dry weights/fed, in the two seasons, were gradually and consistently increased along the three cuts as shown in Tables $(1,2,3$ and 4). Such four characters recorded, for the first, second and third cut, 65.3, 76.1 and $94.2 \mathrm{~cm}$ for plant height; 11.3, 21.1 and 31.6 for number of tillers/plant; $1.80,3.39$ and 5.25 ton/fed for leaves fresh weight and 181.1, 338.6 and 526.9 ton/fed for leaves dry weight, respectively, in the first season. Similar trend was in the second season.

Concerning compost levels, all of the four characters, in both seasons and along the three successive cuts, were gradually increased parallel to the increase in compost level with significant differences between each two compost levels as clearly indicated in Tables (1, 2, 3 and 4). In agreement with these results were the results revealed by Baeck and Park (2001), Khalil (2002), Adholeya and Prakash (2004), Abdou et al. (2012) and Abdou et al. (2014) on basil, rosemary, lemongrass, mint and marjoram, respectively.

As far as NPK/fertilization treatments are concerned, both $100 \%$ NPK and $75 \%$ NPK + E.M. + yeast treatments were significantly equal, for the four growth traits, in the two seasons along the three cuts, in giving taller plants, more tillers number/plant and heavier leaves fresh and dry weight/fed than the other two examined treatments (75\% NPK + E.M. and 75\% NPK + yeast as indicated in Tables (1, 2, 3 and 4). The role of NPK in augmenting various vegetative characters was reported by Sakr (2001) and El-Shora (2009) on mint, Singh et al. (2004) and Rao et al. (2007) on basil, Singh (2004) on rosemary and Rajab (2014) on marjoram. While that of E.M. was revealed by Mazrou (2008), Hussein et al. (2008), Abd El-Raaof (2009), Abdou et al. (2009) and Ali (2013) on lemongrass, marjoram, borage, guar and
African marigold, respectively, meanwhile, the effectiveness of yeast was observed on lemongrass (Naguib, 2002), marjoram (Badran et al., 2002 and El-Hindi and ElBoraie, 2005) and basil (Salman, 2006 and Abd-El-Salam, 2014).

In regard to the interactions between compost levels and NPK/biofertilization treatments, they proved to be significant in both seasons and along the three cuts for plant height, number of tillers/plant and fresh and dry weights of the leaves/fed. The highest values were obtained due to the interaction between the high compost level (8 ton/fed) and either $100 \%$ NPK or $75 \%$ NPK + E.M. + yeast. Each one of these two superior combined treatments gave significantly, in the two seasons and for the three cuts, higher values than the traditional treatment (zero compost plus 100\% NPK) as illustrated in Tables (1, 2, 3 and 4).

\section{2- Essential oil parameters:}

Tables (5 and 6) show that essential oil $\%$ and essential oil yield/fed, in the two seasons, were increased upward from the first cut and up to the third one. In other words, essential oil \% recorded $0.222,0.237$ and $0.253 \%$ for three cuts in the first season; and $0.227,0.244$ and $0.270 \%$ in the second season, respectively. While, essential oil yield/fed were 4.00, 7.92 and 13.39 liter/fed in the first season and 4.99, 7.36 and 11.54 liter/fed in the second season, respectively for the three successive cuts.

In regard to compost levels, both low and high levels caused significant augmentation in essential oil percent and yield per fed in both seasons along the three cuts of control treatment. However, the high level ( 8 ton/fed) was much more effective than the low one (4ton/fed) in this concern as shown in Tables (5 and 6). Numerically, essential oil yield/fed was increased by 29.9 , 37.8 and $33.2 \%$ in the first season and 39.2, 34.1 and $25.3 \%$ in the second season, respectively due to the use of the high compost level in comparison with the control treatment. In agreement with these results 
Table 1. Effect of compost and mineral NPK/biofertilizers treatments on plant height (cm) of lemongrass plants at 2011/2012 and 2012/2013.

\begin{tabular}{|c|c|c|c|c|c|c|c|c|}
\hline \multirow{3}{*}{$\begin{array}{l}\text { NPK/biofertilizer } \\
\text { treatments (B) }\end{array}$} & \multicolumn{8}{|c|}{ Compost levels (ton/fed) (A) } \\
\hline & \multicolumn{4}{|c|}{$1^{\text {st }}$ Season } & \multicolumn{4}{|c|}{$2^{\text {nd }}$ Season } \\
\hline & $\mathbf{0}$ & 4 & 8 & Mean (B) & $\mathbf{0}$ & 4 & 8 & Mean (B) \\
\hline & \multicolumn{8}{|c|}{$\mathbf{1}^{\text {st }} \mathrm{Cut}$} \\
\hline $100 \% \mathrm{NPK}$ & 63.3 & 66.2 & 69.0 & 66.2 & 62.4 & 66.3 & 70.1 & 66.3 \\
\hline $75 \%$ NPK + E.M. & 62.5 & 64.6 & 67.8 & 65.0 & 59.9 & 64.5 & 66.7 & 63.7 \\
\hline $75 \%$ NPK + Y & 60.8 & 62.2 & 65.6 & 62.9 & 57.7 & 62.0 & 65.6 & 61.8 \\
\hline $75 \%$ NPK + E.M. + Y & 65.0 & 66.4 & 69.8 & 67.1 & 61.6 & 65.3 & 69.2 & 65.4 \\
\hline Mean (A) & 62.9 & 64.9 & 68.1 & 65.3 & 60.4 & 64.5 & 67.9 & 64.3 \\
\hline \multirow[t]{2}{*}{ L.S.D. at $5 \%$} & A: 1.9 & \multicolumn{2}{|c|}{ B: 2.2} & AB: 3.8 & A: 2.7 & \multicolumn{2}{|c|}{ B: 2.3} & AB: 4.0 \\
\hline & \multicolumn{8}{|c|}{$2^{\text {nd }}$ Cut } \\
\hline $100 \%$ NPK & 73.0 & 77.3 & 85.6 & 78.6 & 68.1 & 70.9 & 74.9 & 71.3 \\
\hline 75 \% NPK + E.M. & 69.4 & 74.2 & 80.9 & 74.8 & 66.4 & 68.5 & 72.0 & 69.0 \\
\hline $75 \% \mathrm{NPK}+\mathrm{Y}$ & 66.4 & 70.8 & 76.6 & 71.3 & 64.0 & 66.2 & 71.0 & 67.1 \\
\hline $75 \%$ NPK + E.M. + Y & 73.9 & 78.3 & 86.2 & 79.5 & 67.5 & 70.4 & 74.5 & 70.8 \\
\hline Mean (A) & 70.7 & 75.2 & 82.3 & 76.1 & 66.5 & 69.0 & 73.1 & 69.5 \\
\hline \multirow[t]{2}{*}{ L.S.D. at 5\% } & A: 2.6 & \multicolumn{2}{|c|}{ B: 2.5} & AB: 4.3 & A: 2.3 & \multicolumn{2}{|c|}{ B: 2.1} & AB: 3.6 \\
\hline & \multicolumn{8}{|c|}{$3^{\text {rd }}$ Cut } \\
\hline $100 \% \mathrm{NPK}$ & 91.7 & 96.7 & 101.2 & 96.5 & 75.3 & 79.1 & 84.6 & 79.7 \\
\hline 75 \% NPK + E.M. & 90.4 & 93.3 & 96.2 & 93.3 & 72.3 & 76.1 & 81.9 & 76.8 \\
\hline $75 \% \mathrm{NPK}+\mathrm{Y}$ & 89.0 & 89.4 & 93.4 & 90.6 & 70.5 & 74.3 & 80.3 & 75.0 \\
\hline $75 \%$ NPK + E.M. + Y & 92.6 & 96.2 & 100.6 & 96.5 & 74.4 & 79.7 & 83.6 & 79.2 \\
\hline Mean (A) & 90.9 & 93.9 & 97.9 & 94.2 & 73.1 & 77.3 & 82.6 & 77.7 \\
\hline L.S.D. at 5\% & A: 2.9 & & & $\mathrm{AB}: 5.5$ & A: 3.2 & & & AB: 4.8 \\
\hline
\end{tabular}

E.M.: Effective microorganisms Y: Yeast

Table 2. Effect of compost and mineral NPK/biofertilizers treatments on no. of tillers/plant of lemongrass plants at 2011/2012 and 2012/2013.

\begin{tabular}{|c|c|c|c|c|c|c|c|c|}
\hline \multirow{3}{*}{$\begin{array}{l}\text { NPK/biofertilizer } \\
\text { treatments (B) }\end{array}$} & \multicolumn{8}{|c|}{ Compost levels (ton/fed) (A) } \\
\hline & \multicolumn{4}{|c|}{$1^{\text {st }}$ Season } & \multicolumn{4}{|c|}{$2^{\text {nd }}$ Season } \\
\hline & $\mathbf{0}$ & 4 & 8 & Mean (B) & $\mathbf{0}$ & 4 & 8 & Mean (B) \\
\hline & \multicolumn{8}{|c|}{$\mathbf{1}^{\text {st }} \mathrm{Cut}$} \\
\hline $100 \%$ NPK & 11.2 & 11.7 & 12.9 & 11.9 & 13.5 & 15.2 & 17.6 & 15.4 \\
\hline $75 \%$ NPK + E.M. & 10.4 & 10.7 & 11.9 & 11.0 & 12.8 & 14.2 & 16.5 & 14.5 \\
\hline $75 \% \mathrm{NPK}+\mathrm{Y}$ & 9.6 & 9.8 & 11.6 & 10.3 & 11.5 & 13.3 & 15.5 & 13.4 \\
\hline $75 \%$ NPK + E.M. + Y & 10.9 & 11.5 & 13.4 & 11.9 & 13.3 & 15.0 & 17.3 & 15.2 \\
\hline Mean (A) & 10.5 & 10.9 & 12.4 & 11.3 & 12.8 & 14.4 & 16.8 & 14.7 \\
\hline \multirow[t]{2}{*}{ L.S.D. at 5\% } & A: 0.7 & \multicolumn{2}{|c|}{ B: 0.5} & AB: 0.9 & A: 1.2 & \multicolumn{2}{|c|}{ B: 1.0} & AB: 1.7 \\
\hline & \multicolumn{8}{|c|}{$2^{\text {nd }} \mathrm{Cut}$} \\
\hline $100 \% \mathrm{NPK}$ & 20.4 & 22.5 & 24.7 & 22.5 & 18.7 & 21.4 & 24.5 & 21.5 \\
\hline $75 \%$ NPK + E.M. & 18.2 & 20.6 & 22.1 & 20.3 & 17.3 & 20.5 & 22.7 & 20.2 \\
\hline $75 \% \mathrm{NPK}+\mathrm{Y}$ & 17.5 & 19.1 & 21.3 & 19.3 & 15.5 & 18.4 & 22.1 & 18.7 \\
\hline $75 \%$ NPK + E.M. + Y & 19.7 & 22.0 & 24.6 & 22.1 & 18.5 & 21.0 & 24.2 & 21.2 \\
\hline Mean (A) & 19.0 & 21.1 & 23.2 & 21.1 & 17.5 & 20.3 & 23.4 & 20.4 \\
\hline \multirow[t]{2}{*}{ L.S.D. at 5\% } & A: 1.3 & \multicolumn{2}{|c|}{ B: 1.2} & $\mathrm{AB}: 2.1$ & A: 1.6 & \multicolumn{2}{|c|}{ B: 1.8} & $\mathrm{AB}: 3.1$ \\
\hline & \multicolumn{8}{|c|}{$3^{\text {rd }}$ Cut } \\
\hline $100 \%$ NPK & 30.2 & 32.8 & 35.9 & 33.0 & 25.1 & 27.4 & 30.3 & 27.6 \\
\hline $75 \%$ NPK + E.M. & 28.5 & 30.4 & 33.1 & 30.7 & 22.9 & 25.8 & 28.1 & 25.6 \\
\hline $75 \% \mathrm{NPK}+\mathrm{Y}$ & 26.2 & 29.4 & 31.1 & 28.9 & 21.0 & 23.2 & 26.9 & 23.7 \\
\hline $75 \%$ NPK + E.M. + Y & 31.3 & 33.3 & 36.3 & 33.6 & 24.6 & 26.0 & 30.1 & 26.9 \\
\hline Mean (A) & 29.1 & 31.5 & 34.1 & 31.6 & 23.4 & 25.6 & 28.9 & 26.0 \\
\hline L.S.D. at 5\% & A: 1.6 & & & $\mathrm{AB}: 2.8$ & A: 2.0 & & & AB: 3.8 \\
\hline
\end{tabular}

E.M.: Effective microorganisms Y: Yeast 
Table 3. Effect of compost and mineral NPK/biofertilizers treatments on leaves fresh weight (ton/fed) of lemongrass plants at 2011/2012 and 2012/2013.

\begin{tabular}{|c|c|c|c|c|c|c|c|c|}
\hline \multirow{3}{*}{$\begin{array}{l}\text { NPK/biofertilizer } \\
\text { treatments (B) }\end{array}$} & \multicolumn{8}{|c|}{ Compost levels (ton/fed) (A) } \\
\hline & \multicolumn{4}{|c|}{$1^{\text {st }}$ Season } & \multicolumn{4}{|c|}{$2^{\text {nd }}$ Season } \\
\hline & $\mathbf{0}$ & 4 & 8 & Mean (B) & $\mathbf{0}$ & 4 & 8 & Mean (B) \\
\hline & \multicolumn{8}{|c|}{$\mathbf{1}^{\text {st }} \mathrm{Cut}$} \\
\hline $100 \% \mathrm{NPK}$ & 1.80 & 1.86 & 1.92 & 1.86 & 2.05 & 2.36 & 2.59 & 2.33 \\
\hline $75 \%$ NPK + E.M. & 1.72 & 1.77 & 1.84 & 1.78 & 1.80 & 2.22 & 2.45 & 2.16 \\
\hline $75 \% \mathrm{NPK}+\mathrm{Y}$ & 1.65 & 1.68 & 1.73 & 1.69 & 1.67 & 2.07 & 2.17 & 1.97 \\
\hline $75 \%$ NPK + E.M. + Y & 1.83 & 1.87 & 1.93 & 1.88 & 1.99 & 2.32 & 2.56 & 2.29 \\
\hline Mean (A) & 1.75 & 1.80 & 1.86 & 1.80 & 1.88 & 2.24 & 2.44 & 2.19 \\
\hline \multirow[t]{2}{*}{ L.S.D. at $5 \%$} & A: 0.06 & \multicolumn{2}{|c|}{ B: 0.06} & AB: 0.10 & A: 0.16 & \multicolumn{2}{|c|}{ B: 0.14} & AB: 0.24 \\
\hline & \multicolumn{8}{|c|}{$2^{\text {nd }}$ Cut } \\
\hline $100 \% \mathrm{NPK}$ & 3.23 & 3.46 & 3.67 & 3.45 & 2.84 & 3.17 & 3.55 & 3.19 \\
\hline 75 \% NPK + E.M. & 3.16 & 3.38 & 3.54 & 3.36 & 2.60 & 2.94 & 3.34 & 2.96 \\
\hline $75 \% \mathrm{NPK}+\mathrm{Y}$ & 3.08 & 3.26 & 3.46 & 3.27 & 2.45 & 2.73 & 3.14 & 2.77 \\
\hline $75 \%$ NPK + E.M. + Y & 3.28 & 3.48 & 3.69 & 3.48 & 2.81 & 3.09 & 3.49 & 3.13 \\
\hline Mean (A) & 3.19 & 3.40 & 3.59 & 3.39 & 2.68 & 2.98 & 3.38 & 3.01 \\
\hline \multirow[t]{2}{*}{ L.S.D. at 5\% } & A: 0.14 & \multicolumn{2}{|c|}{ B: 0.12} & AB: 0.21 & A: 0.22 & \multicolumn{2}{|c|}{ B: 0.16} & AB: 0.28 \\
\hline & \multicolumn{8}{|c|}{$3^{\text {rd }}$ Cut } \\
\hline $100 \%$ NPK & 5.17 & 5.42 & 5.76 & 5.45 & 4.11 & 4.41 & 4.75 & 4.42 \\
\hline 75 \% NPK + E.M. & 4.94 & 5.19 & 5.51 & 5.21 & 3.89 & 4.28 & 4.55 & 4.24 \\
\hline $75 \% \mathrm{NPK}+\mathrm{Y}$ & 4.60 & 4.83 & 5.23 & 4.88 & 3.57 & 4.04 & 4.38 & 4.00 \\
\hline $75 \%$ NPK + E.M. + Y & 5.19 & 5.47 & 5.78 & 5.48 & 4.09 & 4.36 & 4.69 & 4.38 \\
\hline Mean (A) & 4.98 & 5.23 & 5.57 & 5.26 & 3.91 & 4.28 & 4.59 & 4.26 \\
\hline L.S.D. at $5 \%$ & A: 0.18 & \multicolumn{2}{|c|}{ B: 0.21} & $\mathrm{AB}: 0.36$ & A: 0.25 & \multicolumn{2}{|c|}{ B: 0.20} & AB: 0.34 \\
\hline
\end{tabular}

E.M.: Effective microorganisms $\quad$ Y: Yeast

Table 4. Effect of compost and mineral NPK/biofertilizers treatments on leaves dry weight (kg/fed) of lemongrass plants at 2011/2012 and 2012/2013.

\begin{tabular}{|c|c|c|c|c|c|c|c|c|}
\hline \multirow{3}{*}{$\begin{array}{l}\text { NPK/biofertilizer } \\
\text { treatments }(\mathrm{B})\end{array}$} & \multicolumn{8}{|c|}{ Compost levels (ton/fed) (A) } \\
\hline & \multicolumn{4}{|c|}{$1^{\text {st }}$ Season } & \multicolumn{4}{|c|}{$2^{\text {nd }}$ Season } \\
\hline & $\mathbf{0}$ & 4 & 8 & Mean (B) & $\mathbf{0}$ & 4 & 8 & Mean (B) \\
\hline & \multicolumn{8}{|c|}{$1^{\text {st }} \mathrm{Cut}$} \\
\hline $100 \% \mathrm{NPK}$ & 183.9 & 191.2 & 194.7 & 189.9 & 208.7 & 240.3 & 263.3 & 237.4 \\
\hline $75 \%$ NPK + E.M. & 170.5 & 179.8 & 185.4 & 178.6 & 178.0 & 220.6 & 242.1 & 213.6 \\
\hline $75 \%$ NPK + Y & 159.1 & 167.8 & 167.3 & 164.7 & 164.6 & 203.2 & 218.6 & 195.5 \\
\hline $75 \%$ NPK + E.M. + Y & 185.7 & 191.4 & 197.2 & 191.4 & 206.1 & 236.7 & 260.8 & 234.5 \\
\hline Mean (A) & 174.8 & 182.5 & 186.1 & 181.1 & 189.4 & 225.2 & 246.2 & 220.3 \\
\hline \multirow[t]{2}{*}{ L.S.D. at 5\% } & A: 6.2 & \multicolumn{2}{|c|}{ B: 8.5} & AB: 14.7 & A: 14.3 & \multicolumn{2}{|c|}{ B: 17.4} & AB: 30.1 \\
\hline & \multicolumn{8}{|c|}{$2^{\text {nd }}$ Cut } \\
\hline $100 \% \mathrm{NPK}$ & 327.1 & 351.9 & 372.8 & 350.6 & 288.0 & 320.2 & 360.7 & 323.0 \\
\hline $75 \%$ NPK + E.M. & 312.3 & 300.4 & 348.8 & 320.5 & 256.6 & 292.1 & 327.2 & 292.0 \\
\hline $75 \%$ NPK + Y & 299.8 & 319.1 & 339.7 & 319.5 & 243.3 & 272.6 & 311.3 & 275.7 \\
\hline $75 \%$ NPK + E.M. + Y & 330.7 & 353.0 & 373.7 & 352.5 & 284.2 & 315.3 & 354.6 & 318.0 \\
\hline Mean (A) & 317.5 & 339.5 & 358.8 & 338.6 & 268.0 & 300.0 & 338.6 & 302.2 \\
\hline \multirow[t]{2}{*}{ L.S.D. at 5\% } & A: 15.0 & \multicolumn{2}{|c|}{ B: 13.6} & $\mathrm{AB}: 23.6$ & A: 20.8 & \multicolumn{2}{|c|}{ B: 18.6} & AB: 32.2 \\
\hline & \multicolumn{8}{|c|}{$\mathbf{3}^{\text {rd }}$ Cut } \\
\hline $100 \%$ NPK & 528.8 & 557.0 & 589.1 & 558.3 & 413.2 & 444.6 & 480.2 & 446.0 \\
\hline $75 \%$ NPK + E.M. & 487.2 & 508.9 & 537.8 & 511.3 & 387.3 & 426.5 & 451.4 & 421.7 \\
\hline $75 \% \mathrm{NPK}+\mathrm{Y}$ & 449.4 & 472.2 & 508.2 & 476.6 & 350.6 & 401.2 & 436.0 & 395.9 \\
\hline $75 \%$ NPK + E.M. + Y & 529.3 & 560.1 & 594.2 & 561.2 & 414.8 & 442.1 & 476.1 & 444.3 \\
\hline Mean (A) & 498.7 & 524.6 & 557.3 & 526.9 & 391.5 & 428.7 & 460.9 & 427.0 \\
\hline L.S.D. at 5\% & A: 21.2 & & 5.9 & AB: 44.9 & A: 26.6 & & & AB: 38.1 \\
\hline
\end{tabular}

E.M.: Effective microorganisms Y: Yeast 
Table 5. Effect of compost and mineral NPK/biofertilizers treatments on essential oil \% of lemongrass plants at 2011/2012 and 2012/2013.

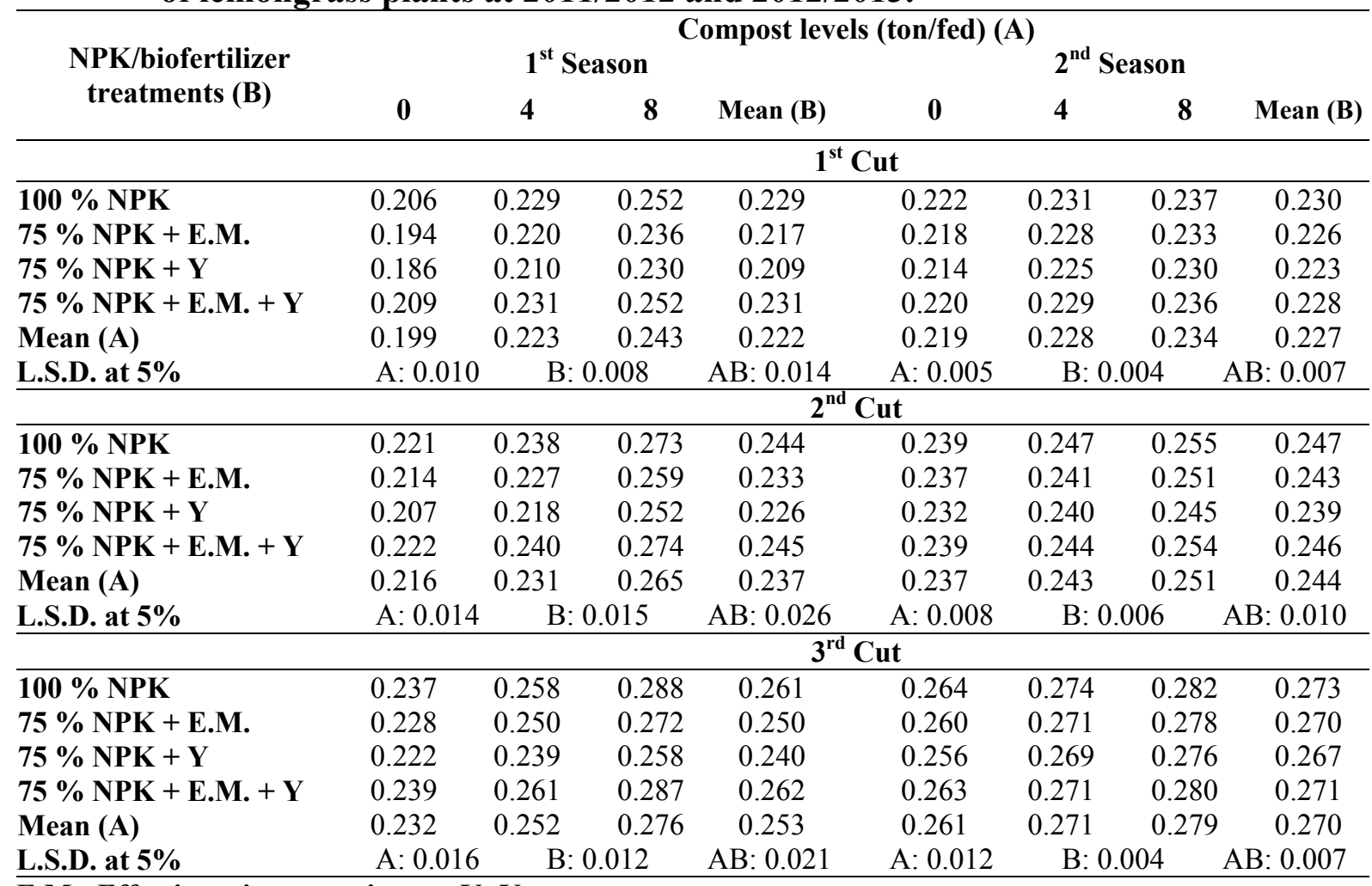

E.M.: Effective microorganisms Y: Yeast

Table 6. Effect of compost and mineral NPK/biofertilizers treatments on essential oil yield (liter/fed.) of lemongrass plants at 2011/2012 and 2012/2013.

\begin{tabular}{|c|c|c|c|c|c|c|c|c|}
\hline \multirow{3}{*}{$\begin{array}{c}\text { NPK/biofertilizer } \\
\text { treatments (B) }\end{array}$} & \multicolumn{8}{|c|}{ Compost levels (ton/fed.) (A) } \\
\hline & \multicolumn{4}{|c|}{$1^{\text {st }}$ Season } & \multicolumn{4}{|c|}{$2^{\text {nd }}$ Season } \\
\hline & $\mathbf{0}$ & 4 & 8 & Mean (B) & $\mathbf{0}$ & 4 & 8 & Mean (B) \\
\hline & \multicolumn{8}{|c|}{$\mathbf{1}^{\text {st }} \mathrm{Cut}$} \\
\hline $100 \% \mathrm{NPK}$ & 3.71 & 4.27 & 4.85 & 4.28 & 4.55 & 5.46 & 6.14 & 5.38 \\
\hline $75 \%$ NPK + E.M. & 3.33 & 3.90 & 4.36 & 3.86 & 3.92 & 5.07 & 5.71 & 4.90 \\
\hline $75 \% \mathrm{NPK}+\mathrm{Y}$ & 3.06 & 3.54 & 3.97 & 3.52 & 3.57 & 4.64 & 5.01 & 4.41 \\
\hline $75 \%$ NPK + E.M. + Y & 3.82 & 4.32 & 4.88 & 4.34 & 4.39 & 5.32 & 6.03 & 5.25 \\
\hline Mean (A) & 3.48 & 4.01 & 4.52 & 4.00 & 4.11 & 5.13 & 5.72 & 4.99 \\
\hline \multirow[t]{2}{*}{ L.S.D. at 5\% } & A: 0.22 & \multicolumn{2}{|c|}{ B: 0.18} & AB: 0.31 & A: 0.54 & \multicolumn{2}{|c|}{ B: 0.31} & AB: 0.54 \\
\hline & \multicolumn{8}{|c|}{$2^{\text {nd }} \mathrm{Cut}$} \\
\hline$\overline{100 \% \mathrm{NPK}}$ & 7.12 & 8.23 & 10.02 & 8.46 & 6.80 & 7.81 & 9.05 & 7.89 \\
\hline $75 \%$ NPK + E.M. & 6.77 & 7.70 & 9.18 & 7.88 & 6.16 & 7.09 & 8.40 & 7.22 \\
\hline $75 \% \mathrm{NPK}+\mathrm{Y}$ & 6.40 & 7.12 & 8.73 & 7.42 & 5.69 & 6.53 & 7.70 & 6.64 \\
\hline $75 \%$ NPK + E.M. + Y & 7.28 & 8.35 & 10.13 & 8.59 & 6.71 & 7.55 & 8.86 & 7.71 \\
\hline Mean (A) & 6.90 & 7.35 & 9.51 & 7.92 & 6.34 & 7.25 & 8.50 & 7.36 \\
\hline \multirow[t]{2}{*}{ L.S.D. at 5\% } & A: 0.31 & \multicolumn{2}{|c|}{ B: 0.28} & AB: 0.48 & A: 0.72 & \multicolumn{2}{|c|}{ B: 0.48} & AB: 0.83 \\
\hline & \multicolumn{8}{|c|}{$3^{\text {rd }} \mathrm{Cut}$} \\
\hline $100 \%$ NPK & 12.12 & 13.99 & 16.59 & 14.23 & 10.86 & 12.08 & 13.38 & 12.11 \\
\hline $75 \%$ NPK + E.M. & 11.28 & 12.95 & 14.97 & 13.07 & 10.12 & 11.60 & 12.64 & 11.45 \\
\hline $75 \% \mathrm{NPK}+\mathrm{Y}$ & 10.50 & 11.53 & 13.51 & 11.85 & 9.15 & 10.91 & 12.09 & 10.72 \\
\hline $75 \%$ NPK + E.M. + Y & 12.40 & 14.28 & 16.58 & 14.42 & 10.75 & 11.83 & 13.12 & 11.90 \\
\hline Mean (A) & 11.57 & 13.19 & 15.41 & 13.39 & 10.22 & 11.60 & 12.81 & 11.54 \\
\hline L.S.D. at 5\% & A: 0.88 & & 92 & $\mathrm{AB}: 1.59$ & A: 1.02 & $\mathrm{~B}:$ & & AB: 0.74 \\
\hline
\end{tabular}

E.M.: Effective microorganisms Y: Yeast 
were the findings of Maheshwari et al. (1991), Naguib (2002) and Adholeya and Prakash (2004) on lemongrass; Khalil (2002) on rosemary, Carlen et al. (2004) on basil, Abdou et al. (2012) on mint and Abdou et al. (2014) on marjoram.

In connection with NPK/biofertilization treatments, significant differences were obtained for both essential oil $\%$ and yield/fed in both seasons as shown in Tables (5 and 6). The highest values were given, for both parameters, by the two treatments of $100 \%$ NPK and $75 \%$ NPK + E.M. + yeast with no significant differences between them. It was found that the use of both E.M. plus yeast in combination with $75 \%$ NPK was much more effective than either E.M. or yeast alone. Therefore, the triple treatment $75 \%$ NPK + E.M. + yeast increased the essential oil yield/fed, over $75 \%$ NPK + yeast and 75\% NPK + E.M., respectively by 23.3 and $12.4 \%$ in the first cut; 15.8 and $9.0 \%$ in the second cut and 21.7 and $10.3 \%$ in the third cut for the first season. The corresponding values for the second season reached 19.0 and $7.1 \%, 16.1$ and $6.8 \%$ and 11.0 and $3.9 \%$. The role of NPK in augmenting essential oil $\%$ and yield was reported by Agina et al. (2001) on lemongrass, Sakr (2001) on mint, Singh (2004) on rosemary, Singh et al. (2004), Golez et al. (2006) and Rao et al. (2007) on basil and Rajab (2014) on marjoram. While that of E.M. was revealed by Harridy et al. (2001) and Mazrou (2008) on lemongrass and Hussein et al. (2008) on marjoram and that of yeast was given by Badran et al. (2002) and El-Hindi and El-Boraie (2005) on marjoram, Salman (2006) and Abd El-Salam (2014) on basil and Shalan (2013) on mint.

Obtained data show that the interactions between compost levels and NPK/biofertilization treatments were significant. The highest values of essential oil $\%$ and yield were obtained when lemongrass plants were supplied with the high level of compost ( 8 ton/fed) and fertilized with either $100 \%$ NPK or $75 \%$ NPK plus E.M. and yeast. Either one of these two combined treatments gave significantly higher essential oil $\%$ and essential oil yield/fed than the conventional NPK fertilization treatment (100\% NPK).

An explanation to the physiological roles of compost and mineral fertilizers, as well as, E.M. and yeast additions in augmenting vegetative growth and essential oil parameters of lemongrass plants could be summarized in the following paragraphs. Concerning compost, Cooke (1972) demonstrated that organic fertilizer from plant sources contain a lot of $\mathrm{N}$ and $\mathrm{P} \%$ and have a little or no soluble salts and added that microorganisms have the ability to supply the plants with fixed N, P and phytohormones that they have to be augmented the growth and N, P and K contents. Schachtschable (1979) proved that organic manure hold moisture and maintains sufficient pore spaces to permit good air circulation and drainage. Follet et al. (1981) proved the positive roles of organic fertilizers such as enhancement of soil properties, organic matter, humus and total nitrogen of soil. They added that microbial decomposition caused faster release of necessary nutrients and most micronutrients have to be more readily available at a wide range of $\mathrm{pH}$.

The role of mineral N, P and K nutrients in augmenting vegetative growth characters and essential oil parameters of lemongrass plants is clearly realized throughout their fundamental roles in plant growth and development. Nitrogen, for instance, is a constituent of amino acids, enzymes and energy transfer materials such as chlorophyll, ADP and ATP, (Bidwell, 1974). Phosphorus is essential for cell division, development of meristematic tissues, carbohydrate transformation, photosynthesis and biological oxidation, (Lambers et al., 2000). While, potassium functions as an osmoticum, reacts synergistically with IAA and carbohydrates translocation, (Mengel and Kirkby, 1987).

Obtained results declared the role of
E.M. (Effective microorganisms) in 
improving different growth aspects and essential oil parameters of lemongrass plants. It contains useful microorganisms including photosynthetic bacteria, lactic acid bacteria, yeasts and others. It is used now in many countries to reduce the amounts of agrochemicals. It is reported by Ho and Hwan (2000) that E.M. is effective in enhancing soil properties, promoting crops yield and augmenting tolerance.

In regard to yeast, Nagodawithana (1991) reported that yeast is a source of many plant growth substances (cytokinins), large amount of vitamin $\mathrm{B}$ and nutritional elements (P, K, S. Na, Ca and $\mathrm{Mg}$ ), as well as, organic compounds (protein, carbohydrates, nucleic acid and lipids). Moreover, Mady (2009) proved that yeast increased endogenous phytohormones like auxins and cytokinins and decreased abscisic acid, while, Khalil and Ismael (2010) mentioned that yeast can play a very good role in making nutrient elements more readily available to plant.

\section{REFERENCES}

Abd El-Raaof, R.M.E. (2009). Response of Borage Plants to Some Organic and Biofertilization Treatments. Ph.D. Thesis, Fac. Agric. Minia Univ., Egypt.

Abd El-Salam, N.M.K. (2014). Response of Sweet Basil Plants to Some Agricultural Treatments. Ph.D. Thesis, Fac. Agric., Minia Univ.

Abdou, M.A.H.; Attia, F.A.; Ahmed, E.T.; El-Sayed, A.A. and Abd-El-Naeem, L.M. (2012). Physiological studies on mint plants. Proc. Second Inter. Conf. of Physiol. Microb. and Ecological Plant Sci. (29-30 April, 2012). Fac. of Science, Minia Univ., pp. 207-228.

Abdou, M.A.H.; Attia, F.A.; Taha, R.A. and Shehata, A.M. (2009). Physiological studies on guar plants. The $5^{\text {th }}$ Inter. of Sustain, Agric. and develop. Fac. of Agric, Fayoum Univ., 21-23 December.

Abdou, M.A.H.; Sharaf El-Din, M.N.; Hussein, H.A. and Rajab, R.M. (2014). Response of marjoram plants to some agricultural treatments. J. Agric. Sci. Mansoura Univ, 41(4):6841-6851.

Adholeya, A. and Prakash, A. (2004). Effect of different organic manures/compost on the herbage and essential oil yield of Cymbopogon winterianus and their influence on the native AM population in a mariginal alfisol. Bioresour Technol. Tanu., 92:311-320.

Agina, E.A.; Attoa, G.I.; El-Khayat, A.S. (2001). Physiological and chemical response of lemongrass (Cymbopogon citratus) plant to some mineral fertilizers. Annals of Agric. Sci., Moshtohor, 39(2):1067-1088.

Ali, F.A.F. (2013). Effect of Organic and Biofertilization Treatments on Pot African Marigold (Calendula officinalis, L.) Plants. M.Sc. Thesis, Fac. Agric., Minia Univ.

Badran, F.S.; Zayed, A.A. and Hussain, M.A. (2002). Response of vegetative growth and yield of herb Majorana hortensis, Moench, plants to potassium fertilization and active yeast. Proc. Sec. Conf. of Sustainable Agric., Fayoum Branch, Cairo Univ.

Baeck, H.W. and Park, K.W. (2001). Effect of substrate and nutrient solution concentration on growth and essential oil content of sweet basil (Ocimum basilicum). Korean Journal of Horticultural Science \& Technology, 19(1):92-97 (Hort. Abst. 72(6):5947).

Bagaturiya, N.S. (1990). Lemongrass essential oil. Pishch Prom-st. (Moscow). 10,48 .

Bidwell, R.G. (1974). Plant Physiology. Macmillan Publishing Co. Inc., New York, U.S.A.

British Pharmacopoeia (1963). Determination of Volatile Oil Drugs. The Pharmaceutical Press, London.

Carlen, Ch.; Neyroud, J.A.; Carron, C.A. and Rey, Ch. (2004). Effect of different organic fertilizer on yield of aromatic and medicinal plants. Revue Suisse de viticulture, Arboriculture et Horticulture, 36(6):263-267. 
Ciaramello, D. (1973). Preliminary study of the use of citronella, lemongrass, palmarosa and vetiver for cellulose and paper production. Biol. Tech. (Inst. Agronomy, Campinas). 1, 24 pp. Campinas, Brazil.

Cooke, G.W. (1972). Fertilizing for Maximum Yield. Richard clay (The Chauer Press) LTD Bungary, Seuffok, Great Britain.

El-Hindi, K.M. and El-Boraie, E.A. (2005). Effect of some biofertilizers on the growth, essential oil and chemical composition of marjoram plants. J. Agric. Sci. Mansoura Univ., 30(12):7912-7928.

El-Shora, S.H.A. (2009). Physiological Studies on Mentha spp. (fertilization-post harvest treatments). M.Sc. Thesis. Fac. Agric., Moshtohor, Benha Univ.

Follet, R.H.; Murphy, L.S. and Donahue, R.I. (1981). Fertilizers and Soil Amendments. Prentice Hall Inc., Englewood Cliffs, N.J., U.S.A.

Golez, A.; Politycka, B. and Lozykowska, S. (2006). The effect of nitrogen fertilization and stage of plant development on the mass and quality of sweet basil leaves (Ocimum basilicum, L.). ERBA Polonica, 52(112):22-30.

Harridy, I.M.A.; Soliman, S.G.I. and Amara, M.A.T. (2001). Physiological, chemical and biological studies on lemongrass (Cymbopogon citratus) (DC) Stapf in response to diazotrophic bacteria. J. Agric. Sci. Mansoura Univ., 26(10):61316152.

Ho, H.N. and Hwan, K.J. (2000). The study on the plant growth hormones in E.M., a case study. Conf. E.M. Technology and nature farming, Pyong Yong, DTR, Korea.

Hussein, H.A.A.; El-Hindi, K.M. and Shalan, M.M.N. (2008). Efficiency of organic and bio-fertilizers on growth, yield and essential oil of marjoram (Majorana hortensis L.). Plants. J. Agric. Sci. Mansoura Univ., 33(10):7383-7401.

Khalil, M.Y. (2002). Influence of compost and foliar fertilization on growth, chemical composition of Rosmarinus officinalis, L. Egypt. J. Appl. Sci., 17(10):684-699.

Khalil, S.E. and Ismael, E.G. (2010). Growth, yield and seed quality of Lupinus termis as affected by different soil moisture levels and different ways of yeast application. J. Amer. Sci., 6(8):141-153.

Lambers, H.; Chapin, F.S. and Pons, T.L. (2000). Plant Physiology \& Ecology. Springer, Verleg Inc., New york, U.S.A.

Mady, M.A. (2009). Effect of foliar application with yeast extract and zinc on fruit setting and yield of faba bean (Vicia faba, L.). J. Biol. Chem. \& Env. Sci., 4(20):109-127.

Maheshwari, S.K.; Gangrade, S.K. and Trivedi, K.C. (1991). Comparative response of palmarosa (lemongrass) to Azotobacter and nitrogen under rain-fed and irrigated swards. Indian-Perfumer., 35(2):108-111.

Mazrou, R.M. (2008). Biotechnological Studies on Cymbopogon citratus Stapf. (Lemongrass). Ph.D. Thesis., Genetic Engineering and Biotechnology Institute, Minufiya Univ.

Mengel, K. and Kirkby, A. (1987). Principles of Plant Nutrition, $4^{\text {th }}$ Ed. Inter Potash Institute, Bem, Switzerland.

MSTAT-C (1986). A Microcomputer Program for the Design, Management and Analysis of Agronomic Research Experiments (Version 4.0), Michigan Stat Univ., U.S.

Nagodawithana, W.T. (1991). Yeast Technology Universal Foods Corporation. Milwoukee, Wiskonsin, Published by Van Nostrand Reinhold, New York, U.S.A.

Naguib, N.Y. (2002). Yield and quality of lemongrass plants (Cymbopogon flexuous stapf) as influenced by farmyard manure and foliar application of bread yeast. Annals Agric. Sci., Ain Shams Univ., 47(3):859-873.

Rajab, R.M. (2014). Response of Marjoram Plants to Some Agricultural Treatments. M.Sc. Thesis Fac. Agric., Mansoura Univ. 


\section{M.A.H. Abdou et al.}

Rao, E.V.; Puttanna, K.; Rao, R.S. and Ramesh, S. (2007). Nitrogen and potassium nutrition of French basil (Ocimum basilicum, Linn.). J. of Spices and Aromatic Crops, 16(2):99-105.

Sakr, W.R.A.S. (2001). Effect of some organic and inorganic fertilizers on Mentha piperita. L. M.Sc. Thesis. Fac. Agric., Cairo Univ., Egypt.

Salman, A.S. (2006). Effect of biofertilization on Ocimum basilicum, L. plant. Egypt. J. Agric. Res., 79(2):587-606.

Schachtschable, S. (1979). Lchrobuch der B.O. deskund. Printed in Germany (F.R.G.) Fedinaudenke, Stuttgard, Germany.
Shalan, M.M.N. (2013). Effect of Some Organic and Bio-Fertilizers on Quality and Quantity of Mentha piperita Oil. Ph.D. Thesis, Fac. Agric. Mansoura Univ., Egypt.

Singh, K.; Singh, P.; Beg. S.; Kumar, D. and Patra, D. (2004). Effect of NPK fertilizers on growth, oil yield and quality of French basil (Ocimum basilicum, L.). J. spices and Aromatic Crops, 13(1):5254.

Singh, M. (2004). Effect of plant spacing, fertilizer, modified urea material and irrigation regime on herbage, oil yield and oil quality of rosemary in semi-arid tropical conditions. J. Hort. Sci. and biotechnology, 79(3):411-415.

\footnotetext{
تأثير الكمبوست و NPK مع التسميا الحيوي على النمو وإنتاج الزيث الطيار في نباتات حشيشة الليمون الئن المون 